\title{
BREVES CONSIDERAÇÕES \\ SOBRE A PRISÃO CIVIL NA \\ INFIDELIDADE DEPOSITÁRIA
}

\author{
Rita de Cássia Resquetti Tarifa* \\ Zilda Mara Consalter
}

SUMÁRIO: 1. Introdução. 2. Contrato de alienação fiduciária. 2.1. Origem. 2.2. Conceito e características. 2.3. Natureza jurídica. 2.4. Legislação Pertinente. 2.5. Procedimento. 3. Depositário infiel. 4. Prisão Civil. 4.1. Prisão. 4.2. Previsóes constitucionais. 4.3. Tratados internacionais. 4.4. Legislação infraconstitucional. 5. A prisão civil do depositário infiel no contrato de alienação fiduciária. 6.Conclusão. 7. Bibliografia.

SUMMARY: 1. Introduction. 2. Contract of fiduciary alienation. 3. Unfaithful Receiver. 4.Civil Prison. 5. The unfaithful receiver's civil prison in the contract of fiduciary alienation. 6. Conclusion. 7. Bibliography.

SUMARIO: 1. Introducción. 2. Contrato de alineación fiduciária. 3. Depositario infiel. 4. Prisión Civil. 5. La prisión civil del depositario infiel en el contrato de alineación fiduciária. 6. Conclusión. 7. Bibliografia.

RESUMO: O Decreto Lei n. 911/69 determina a equiparação do contrato de alienação fiduciária em garantia ao de depósito, quando prevê a possibilidade de decretação de pena de prisão por depositário infiel. Entretanto, o posicionamento mais moderno coaduna-se com a previsão constante no Pacto de São José da Costa Rica, que proíbe a pena de prisão por dívida, excepcionando apenas e tão somente a dívida de caráter alimentar.

ABSTRACT: The Law 911/69 determine the equalization of the contract of fiduciary alienation in warranty to the deposit contract, when it foresees the possibility of prison feather for unfaithful receiver. However, the most modern positioning is incorporated with the forecast in San Jose da Costa Rica's Pact, that prohibit the prison feather for debt, just excepting the debt of alimentary character. 
RESUMEN: EI Decreto Ley n. 911/69 determina la equiparacion del contrato de alineación fiduciaria en garantia del deposito, cuando preve la posibilidad de decreto de pena de prisión por depositario infiel. Sin embargo, la posición más moderna se asocia con la previsión constante en el Pacto de San José da Costa Rica, que prohíbe la pena de prisión por deuda, exceptuándose apenas y solamente la deuda de carácter alimentício.

PALAVRAS-CHAVE: Contrato. Alienação Fiduciaria Depositário Infiel. Prisão Civil por Divida. Decreto 911/69. Pacto de São José da Costa Rica

WORD-KEYS: Contract. Fiduciary Alenation. Unfaithful Receivet. Civil Prison for Debt. Law 911/69. San José da Costa Rica's Pact.

PALABRAS-LLAVE: Contrato. Alineación Fiduciána. Depositario Infrel. Prisión por Deuda. Decreto Ley $911 / 69$. Pacto de San José da Costa Rica.

\section{Introdução}

Aceitar que o contrato de depósito está presente no Decreto-Leí n. 911/69 é coadunar com a possibilidade de decretação de prisão civil por dívida advinda de contrato de alienação fiduciária.

Essa assertiva se confirma porque, a princípio, somente o contrato de depósito é que permite a prisão quando o depositário aliena ou transfere, a qualquer título, o bem pelo qual era responsável.

Assim, a discussão da aceitação do contrato de depósito na seara do contrato de alienação fiduciária em garantia, gira em torno e tangencia a todo momento, os argumentos contrários e favoráveis à prisão por dívida, na qual, por via oblíqua, se passa a conceber - ou não - aquele primeiro contrato como inserto neste último.

Muitos são os argumentos nos dois sentidos, sendo que ponderosas são as razões expendidas tanto pela doutrina quanto pela jurisprudễncia para defender e para combater a equiparação proposta pelas disposições do mencionado Decreto Lei.

Se por um lado visa-se a segurança no cumprimento da obrigação pactuada no contrato de alienação fiduciária - isto com o amparo da Carta Magna; de outro, critica-se instituto nascido entre os romanos, cujo entendimento apontava para o pagamento da dívida pelo trabalho escravo do devedor e que vai de encontro com a postura moderna internacional, traduzida no conteúdo do Pacto de São José da Costa Rica. 
O fato é que nem os dois Tribunais mais elevados de nosso País chegaram a um ponto convergente, sendo que o Supremo Tribunal Federal formalista e tradicional - confirma a legitimidade da prisão civil por dívida contraída em contrato de alienação fiduciária em garantia e o Superior Tribunal de Justiça - mais inovador e em sintonia com o pensamento moderno - desaprova totalmente tal prática, que considera abusiva.

Assim, as presentes considerações podem se delimitar pela tentativa de resposta às seguintes formulações: seria o inadimplemento obrigacional do depositário motivo para se privar sua liberdade? Até que ponto se poderia entender como depositário o alienante fiduciário?

Diante deste cenário em dicotomia, impossível chegar-se a um ponto de vista que não encontre farta e calorosa contra-argumentação dos adeptos da teoria diametralmente oposta.

\section{Contrato de alienação fíduciária}

\subsection{Origem}

Quanto ao nascimento do instituto, remonta ao Direito Romano, à época da Lei das XII Tábuas, tendo surgido tão somente como obrigação moral. Em Roma, local de seu surgimento, este instituto servia a uma variedade de funções e envolvia a transferência da propriedade da coisa ao accipiens, que ficava de restitui-la ao tradens, com a extinção da dívida deste, no caso de penhor, esgotamento do prazo do empréstimo, no comodato ou no momento em que reclamava a devolução, no depósito.

Naquela prisca era, a fidúcia consistia na transferência da propriedade da coisa para a pessoa do credor, em garantia da dívida, revertendo a mesma à propriedade do devedor, uma vez liquidado o débito.

Importante ressaltar que, entre os romanos, se o devedor não cumprisse a obrigação o credor passaria a possuir a coisa que lhe foi transferida apenas como garantia.

Já etimologicamente, a palavra fiduciário vem do latim fiduciae, que significa confiança, segurança.

A fidúcia romana desenvolveu-se, chegando até os dias atuais, adequando-se às exigências da sociedade moderna. De fato, é considerado o primeiro meio de garantia do crédito. 


\subsection{Conceito e características}

A alienação fiduciária é um negócio jurídico em que de um lado há o devedor alienante, possuidor direto do bem dado em garantia, e de outro o credor fiduciário, detentor do domínio e da posse indireta daquele bem.

Para Orlando Gomes ${ }^{1}$, é o negócio jurídico pelo qual o devedor, para garantir o pagamento da dívida, transmite ao credor a propriedade de um bem, retendothe a posse direta, sob a condição resolutiva de saldáta. Ela permite o pagamento à vista de bens móveis com recursos pertencentes a terceiro, geralmente instituição financeira, mas admite-se também empresas de consórcio, desde que devidamente registradas. A esta é feita a transferência da propriedade resolúvel e da posse indireta da coisa, remanescendo o devedor como possuidor direto e depositário até que a dívida seja integralizada.

São sujeitos deste contrato tanto o fiduciante (alienante) quanto o fiduciário (adquirente) e para que seja legítima essa alienação do bem, é necessário que o consumidor final obtenha crédito junto à financeira, passando assim, a ocupar a posição de devedor fiduciário.

Sendo o devedor possuidor direto do bem e depositário do mesmo, tem ele o dever de restituí-lo no caso de inadimplemento da obrigação assumida junto ao credor.

Pode-se considerá-la um pacto acessório, cuja finalidade é a de garantir o cumprimento de um contrato, como o mútuo ou ofinanciamento de bens móveis duráveis.

É necessário o registro do contrato no Cartório de Registro de Títulos e Documentos, a par de alguns entendimentos contrários ${ }^{2}$.

Neste sentido:

...A Alienação Fiduciária em Garantia constituir-se-á pela transcrição do contrato no Cartório de Registro de Títulos e Documentos da comarca do domicílio do credor. Tal conclusão se dá, ao realizarmos uma simbiose do disposto no $\$ 1^{a}$ do art. 66 , conforme a nova redação dada pelo Decreto-lei 99, de 1 de outubro de 1969 e do estatuído no $\$ 5^{\text {a }}$ do artigo 126 do Decreto-lei $\mathrm{n}^{\mathrm{a}} 1000$ de 21 de outubro de 1969 . Contudo, convém que o registro se faça também no domicílio do devedor, se no contrato estiverem estabelecidas outras obrigações... ${ }^{3}$

\footnotetext{
${ }^{1}$ GOMES, Onlando. Contratos, 120 ed, Rio, Forense, 1993, p. 520.

${ }^{2}$ Em contrario: RT 515/139,

"ANDRADE, José Â. de. Da Alienação Fiduciaria em Garantia. São Paulo: Edição Universitária de Dircito, 1970, p.67/68
} 
Antes do registro, o contrato de alienação fiduciária em garantia é apenas título de constituição da propriedade fiduciária, que ainda não nasceu, porquanto seu nascimento depende do competente registro desse título. ${ }^{4}$

\subsection{Natureza jurídica}

Quando se determina a natureza jurídica de um instituto, procede-se um enquadramento dentro de uma das categorias dogmáticas admitidas no ordenamento jurídico. Há várias correntes, seja considerando-a como uma compra e venda com condição resolutiva, seja como propriedade resolúvel onerada com encargo:

Examinando-se a estrutura da alienação fiduciária em garantia, quer no teor original do art.66 da Lei 4728, quer na nova redação que a esse dispositivo deu o art. $1^{\underline{a}}$ do Decreto-lei $n^{\underline{a}}$ 911, verifica-se, de imediato, que se trata de negócio jurídico bilateral, que visa a transferir a propriedade de coisa móvel com fins de garantia. ${ }^{5}$

Para Moreira Alves 6 , os autores não distinguem adequadamente a alienação fiduciária dos demais institutos. Para ele, não se confunde com a propriedade fiduciária, que entende ser um negócio jurídico típico, ou seja, tão somente um contrato que serve de título à constituição da propriedade fiduciária (esta, sim, seria a garantia real)

Deste modo, esse contrato não se enquadra, para referido autor, entre os negócios fiduciários propriamente ditos, ainda que se assemelhe ao chattel morgage e ao trust receipt, sendo um instrumento próprio do Direito Brasileiro.

Para Sílvio Rodrigues ${ }^{7}$, possui a natureza de compra e venda sob condição resolutiva, pois o negócio se consuma desde logo e produz todos os seus efeitos. Ele resolve-se ou desfaz-se, ocorrendo o evento futuro e incerto representado pelo pagamento do débito pelo devedor-alienante Já para Arnoldo Wald, caracteriza-se como propriedade resolúvel e onerada com encargo. ${ }^{8}$

Conforme Cezar Fiúza ${ }^{9}$, há as seguintes teorias básicas a seu respeito: a do duplo efeito, em que caracteriza a confluência de dois contratos distintos e independentes (transmissão de domínio) e o segundo, de caráter obrigacional; e a teoria da propriedade resolúvel, onde há um só negócio e, pactuada a cláusula de garantia, o domínio se torna resolúvel.

\footnotetext{
${ }^{4}$ MOREIRA ALVES, José Carlos. Da Alienação Fiduciária em Garantia. Rio de Janeiro: Forense, 1979, p.76). ${ }^{5}$ MOREIRA ALVES, José Carlos. Op.cit., p. 37.

" MOREIRA ALVES, José Carlos. Op. Cit., p.32.

7 RODRIGUES, Silvio. Direito Civil - Dos contratos e das declarações unilaterais de vontade. $3^{\text {a }}$ vol., $7^{\circ}$ ed., São Paulo, Saraiva, 1977, p. 182.

" WALD, Arnoldo. Curso de Direito Civil Brasileiro - Obrigações e Contratos. $10^{\circ}$ ed., São Paulo, RT, 1992, p. 267/8). "FIUZA, Cezar. Alienação Fiduciária em Garantia. Rio de Janeiro: AIDE, 2000, p.41.
} 
Bem, o fato é que a natureza jurídica deste contrato diz respeito diretamente ao tema da prisão civil por dívida, no sentido de que, se se considerar que o depositário guarda e toma conta de algo que não é seu, e no contrato de alienação fiduciária se mantém consigo algo que se possui, não se poderia falar em depósito, mesmo que por equiparação, pois se estaria desconfigurando totalmente aquele contrato.

Dentro desta afirmação o professor Álvaro Villaça Azevedo se manifesta dizendo que Depositário, assim, é aquele que guarda bem alheio (não próprio!), não se podendo, por isso, dizer que o devedor-fiduciante é, em verdade, depositário, se é ele quem corre todo o risco da perda da coisa desde o início do negócio ${ }^{10}$.

A questão é que a teoria favorável à aplicação de pena de prisão por dívida sofre um sério abalo diante deste argumento...

\subsection{Legislação pertinente}

Com a Lei de Mercado de Capitais (Lei 4728, de 14.7.1965) é que o instituto foi introduzido no país. Foi o Decreto Lei 911 (de 1.10.1969) que the deu corpo.

Bem mais tarde, foi publicada a Lei $n^{2} 9.514$, de 20 de novembro de 1997, dispondo sobre o Sistema de Financiamento Imobiliário, instituindo a alienação fiduciária de coisa imóvel, visando dar maior amplitude ao instituto (embora seja passível de crítica, uma vez que o conceito de contrato de alienação fiduciária contém o termo "coisa móvel"11).

\subsection{Procedimento}

Uma vez perfectibilizada a pactuação - e em não havendo o adimplemento do devedor - o credor do contrato de alienação fiduciária tem três alternativas processuais:

A primeira é propor ação de busca e apreensão da coisa (com medida liminar, desde que comprovada a mora do devedor por meio de carta registrada expedida através do Cartório de Registro de Títulos e Documentos ou pelo protesto do título, a critério do credor).

\footnotetext{
10 Opiniano esposada na obra Prisâ Civi por Divida, p. 109.

1) Para Clóvis Beyiaqua, o contrato de alienaça fiduciária en garantia é o contrato pelo qual uma pessoa recebe un objeto móvel alheio, con a obrigąăo de guatálo e restitutulo em seguida, sendo que compartilham da mesma concepço Orlando Gomes, Barros Monteiro, Wald e Pontes de Miranda. 
Neste caso, o devedor será citado para em 3 dias contestar, ou requerer a purgação da mora se já tiver pago mais de $40 \%$ da dívida (opção quase que inexistente atualmente). Após o devido processamento, o juiz proferirá sentença.

Há a permissão ao credor de, após a apreensão da coisa, proceder à venda da mesma independente de hasta pública, avaliação prévia ou outra medida judicial, salvo disposição em contrário. Nestas condiçōes, o preço não poderá ser considerado vil.

Outra opção ao credor seria a de propor execução da quantia certa a que tem direito, ou seja, aquela correspondente ao saldo devedor do contrato.

Neste caso, quando da necessidade de se efetuar a penhora, ela deverá ser procedida sobre outros bens que bastem para assegurar o pagamento da divida.

A última escolha ao credor em caso de contrato não cumprido é a de propor ação de depósito.

Esta ocorre, geralmente, quando não se encontra o bem alienado fiduciariamente - antes ou após o ajuizamento da busca e apreensão - e, neste caso, requer-se a conversão nos mesmos autos e, de conseqüência, a pena de prisão do devedor, com base na equiparação feita ao contrato de depósito especificado no Código Civil ${ }^{12}$, através do Decreto Lei n. 911/69.

Este procedimento, portanto, é aquele que gera todo um conflito legal, doutrinário e jurisprudencial ao seu redor que se encontra, até hoje, sem um ponto de convergência.

\section{Depositário infiel}

Mattirolo, citado por Marcus Cláudio Acquaviva informa que o instituto do depositário infiel criou-se mediante uma seqüência histórica:... o arresto pessoal por dívida percorreu três estádios principais apresentando três caracteres diversos. Primeiro foi escravidão: tornava-se o devedor escravo do credor, e com o fruto de seu trabalho solvia o débito. Depois tomou o caráter de prisão infligida pelo credor ao devedor como pena, pelo não cumprimento da obrigação. E finalmente, deixou de ser considerada como pena, para tornar-se meio de pôr em prova a solvência do devedor. Este, medido na prisão, não é obrigado a trabalhar para o credor, nem o encarceramento é aplicado como pena ao devedor, e sim como ameaça, com o único intuito de obrigá-lo, por meio eficaz, a despojar-se de suas últimas economias ocultadas na execução, ou a fazer apelo à caridade de seus parentes e amigos, para evitar o vexame da prisão ${ }^{13}$.

12 Artigos 627 e seguintes do Código Civil.

13 Mattirolo, Comentátios ao $\mathrm{CPC}_{\text {, }}$ in ACQUAVIVA, Marcus Cláudio. Dicionário Juridico Brasileiro, p. 688. 
Etimologicamente, a palavra depositário é originária do vocábulo latim deponere e designa pessoa a quem se entrega ou a quem se confia alguma coisa, em depósito.

Na seara juridica, depositário infiel é Aquele que, tendo sob sua guarda bem próprio ou alheio, do qual não tem a livre disponibilidade, dele se desfaz em prejuízo de outrem, incidindo na cominação de prisão civil ${ }^{4}$.

Como dito, para o depositário infiel é aplicada uma pena - termo aí utilizado em sentido lato ", que ganha amparo, inclusive, da Constituição Federal ${ }^{15}$.

Esta pena poderá ser aplicada em duas hipóteses: a) em face de um contrato de depósito (artigo 652, CCB/2002); e b) em razão de fraude à posição processual do executado, que, tendo sob sua própria guarda os bens que the foram penhorados, destes se desfaz indevidamente (artigo 902, $\$ 1$ a, CPC).

Mais uma ver, esbarra-se na questão da aplicação desta pena ao contrato de alienação fiduciária em garantia, posto que a legislação pertinente é taxativa e, por tratar-se de pena restritiva de direitos, não pode ser interpretada extensivamente.

Para tratar-se do depositário infiel, mister verificar-se a questão da responsabilidade pessoal, antigamente regente dos casos de descumprimento das avenças. $O$ devedor respondia com sua liberdade pessoal pelo inadimplemento:

Como dice Besta, originariamente la responsabilidad há sido la exposicion de la persona o de la cosa de ujn deudor ex delicto o ex contractu a la agresión de aquél que recibió la promesa de uma compensación material por el rescate o de quien recibe, em general, la promesa de uma prestación. La idéia motriz es que uma verdadera obligación em sentido jurídico no surge más que cuando a um deber se yuxtapone lá situación personal de cautividad o la vinculación del patrimônio como garantia. Sabemos también que originariamente la responsabilidad há sido uma responsabilidad personal, pero que la evolucion del Derecho Moderno há conducido a uma responsabilidad patromonial.(...) La responsabilidad del deudor es patrimonial. A contrario sensu, ello significa que no existe uma responsabilidad personal o uma responsabilidad que se haga efectiva sobre la própria persona como consecuencia del incunplimineto de lãs obligaciones. Sabiemos yá que este era, em cambio, el sistema de los Derechos primitivos y que toda la evolución jurídica há sido um largo camino para la liberacion de esta responsabilidad personal del deudor....Sólo a partir da la Lex Poetelia aparece um sistema de responsabilidad patrimonial. ${ }^{16}$

\footnotetext{
14 Marcus Cláudio Acquaviva, op. cit., p. 322.

is CP/88, artigo $5^{2}$, inciso LXVIL.

to Diez-PICAZO, Luiz. Fundamentos del Derecho Civil Patrimonial. Madrid: Civitas, 1996, p.123, comentando a evolução da responsabilizaça civil em caso de inadimplemento.
} 
Por vezes, confere-se ao conceito de depositário uma significado muito amplo. Muitas vezes, tal amplitude apenas embasa o cerceamento da liberdade como garantia de questões meramente patrimoniais, erigindo a segurança do crédito como valor superior ao direito de ir e vir.

Cite-se, por oportuno, algumas características do contrato de depósito.

O depósito é o contrato pelo qual um dos contraentes (depositário) recebe do outro (depositante) um bem móvel, obrigando-se a guardá-lo, temporária e gratuitamente, para restituí-lo quando lhe for exigido. Pode ser voluntário ou necessário. Em ambas as hipóteses, o depositário que não o restituir quando exigido será compelido a fazê-lo mediante prisão não excedente a um ano, e ressarcir os prejuízos.

Além desta, são características do depósito:

- a entrega da coisa pelo depositante ao depositário (a tradição da coisa depositada é indispensável ao aperfeiçoamento do contrato salvo, evidentemente, quando a coisa já estiver em poder do depositário, isto é, se a tradição, por uma razão ou outra houver ocorrido anteriormente à celebração do contrato);

- a natureza móvel do bem depositado;

- a entrega da coisa para o fim de ser guardada;

- a restituição da coisa quando reclamada pelo depositante (constitui-se no elemento moral do contrato, cujo descumprimento é passível de acarretar sanções);

- a temporariedade e gratuidade do depósito (pode haver estipulação de gratificação, entretanto)

\section{Prisão Civil}

\subsection{Prisão}

Como muito bem dispõe Moreira Alves ${ }^{17}$, para que se possa conceber como legítima uma ordem de prisão, deve ela atender, primacialmente, no Estado de Direito, ao princípio de que ninguém será constrangido senão por força de uma norma.

A prisão civil foi prevista pelo Código de Hamurabi, onde se uma pessoa tinha contra outra um crédito de trigo ou de prata e se o credor tomasse, em garantia desse crédito, uma pessoa; e se esta pessoa executada morresse, de morte natural, na casa do mesmo credor, não havia motivo para reclamação. Se o executado morresse por outra causa, haveria a condenação do credor. Também 
se o executado fosse filho de um homem livre, deveria ser morto o filho do credor; se escravo, de homem, livre, deveria o credor pagar um terço de mina de prata, perdendo todo o seu crédito.

Se uma pessoa se tornasse dependente de outra, em razão de uma dívida, e se esse devedor houvesse vendido sua esposa, filho ou filha, ou os houvesse dado em serviços, estes laborariam três anos na casa do credor.

No Direito Romano também existiu tal instituto, em decorrência do nexum, pelo descumprimento de obrigação. A partir da Lex Poetelia Papiria, com a execução patrimonial, o instituto foi se desenvolvendo.

\subsection{Previsões constitucionais}

Traçando-se um breve histórico das Constituições, após a Constituição do Império, de 1824, bem como a da República de 1891, serem completamente omissas quanto ao tema, verifica-se que a de 1934 vedava qualquer tipo de prisão ${ }^{18}$.

A Carta outorgada em seguida deixou de considerar a garantia em causa contra a privação da liberdade, sendo que a partir da Constituição de 1937 procedeu-se a ressalva no caso de inadimplemento de prestação de alimentos e no do depositário infiel, nosso objeto do breve estudo.

Em nosso sistema jurídico, a prisão civil somente é admitida em duas hipóteses, previstas pelo art. 5ª LXVII, da Magna Carta de 1988:

"Art. 5". Todos são iguais perante a lei, sem distinção de qualquer nature$\mathrm{za}$, garantindo-se aos brasileiros e aos estrangeiros residentes no País a inviolabilidade do direito à vida, à liberdade, à igualdade, à segurança e à propriedade, nos termos seguintes:

(...)

LXVII. Não haverá prisão civil por dívida, salvo a do responsável pelo inadimplemento voluntário e inescusável de obrigação alimentícia e a do depositário infiel". (grifos nossos)

\subsection{Tratados internacionais}

Por outro lado, a Convenção Interamericana de Direitos Humanos (Pacto de São José da Costa Rica), incorporada em nosso direito positivo pelo Decreto $\mathrm{n}^{\underline{a}}$ 678/92, somente admite a prisão no caso de inadimplemento de obrigação alimentar, como a seguir se transcreve:

2a "Não haverá prisão por drvidas, mulas ou custas." 
"Art. 7". Direito à liberdade pessoal.

$\S 7$ a . Ninguém deve ser detido por dívidas. Este princípio não limita os mandados de autoridade judiciária competente expedidos em virtude de inadimplemento de obrigação alimentar”.

\subsection{Legislação infraconstitucional}

O Código Civil de 1916, por sua vez, assim tratava a questão: "Art. 1.287 - Seja voluntário ou necessário o depósito, o depositário, que o não restituir, quando exigido, será compelido a fazê-lo, mediante prisão não excedente a 1 (um) ano, e a ressarcir os prejuízos (art. 1.273)”.

Seguindo o mesmo caminho, o Código Civil de 2002:

"Art. 652. Seja o depósito voluntário ou necessário, o depositário que não o restituir quando exigido será compelido a fazê-lo mediante prisão não excedente a um ano, e ressarcir os prejuízos" .

O Decreto-Lei $\mathrm{n}^{\mathrm{a}}$. 911/69 mandou aplicar as mesmas disposições para a alienação fiduciária, neste diploma que, para alguns, equiparar-se-ia ao contrato de depósito, cujo art. $4^{\underline{a}}$ dispõe:

"Art. 4". Se o bem alienado fiduciariamente não for encontrado ou não se achar na posse do devedor, o credor poderá requerer a conversão do pedido de busca e apreensão, nos mesmos autos, em ação de depósito, na forma prevista no Capítulo II, do Título I, do Livro IV, do Código de Processo Civil”.

$\mathrm{O}$ problema surge justamente quando se analisa tal dispositivo. Nesse contexto, questiona André Luiz de Andrade Carneiro ${ }^{19}$ : estaria tal conclusão em conformidade com a legislação em vigor e com os princípios norteadores do atual ordenamento jurídico? Para tanto, expor-se-á os argumentos existentes acerca do tema.

\section{A prisão civil do depositário infiel no contrato de alienação fiduciária}

De forma mais restrita, quando se efetua o cruzamento entre as idéias e concepções acerca dos dois institutos acima abordados, muito há que se considerar, a iniciar-se pelo caráter da pena de prisão por dívida. E dívida contraída na esfera civil.

Primeiramente, importante ressaltar que, no aspecto técnico, a prisão civil não tem caráter de pena, como prevista no Direito Penal, mas sim

\footnotetext{
${ }^{19}$ CARNEIRO, André Luiz de Andrade. Breves comentários acerca da prisão civil decorrente da alienação fiduciária em garantia. Disponível em http:/www1.jus.com.br/doutrina/texto.asp?id=4107, capturado $\mathrm{cm} \mathrm{22/10/03.}$
} 
de um meio de coerção para compelir alguém que se colocou na posição de depositário infiel a cumprir o compromisso assumido com o auxiliar da justiça. É por isso que não está sujeita às regras de extinção ou cumprimento de pena, preceituado no Código Penal ${ }^{20}$.

É que o direito à liberdade tem tutela constitucional e, portanto a sua agressão só poderá acontecer por exceção, após um amplo procedimento legal previsto, onde se observou princípios consagrados, como do devido processo legal, juízo natural, princípio da inocência, inafastabilidade do controle jurisdicional, motivação das decisões e tantos outros.

Assim, impende considerar, antes de mais nada, que a privação de liberdade do ser humano necessita, dentro de um Estado Democrático de Direito, ser precedida do devido processo legal. E a ficção instituída pelo Decreto-lei n. $911 / 69$ não obedece este preceito de segurança jurídica.

Além disso, os contemporâneos penalistas vêm difundindo a idéia de substituição da pena privativa de liberdade por outros meios, por comprovadamente não atender aos fins a que se destinaria:

(...) Para que não pairem dúvidas quanto à ilegitimidade e descabimento da prisão civil do devedor no contrato de alienação fiduciária, cabe salientar que, mesmo no Direito Penal, ramo do Direito em que se busca a correção do infrator, geralmente com a aplicação da pena de prisão, como advento de novas correntes de pensamento, indica-se cada vez menos o implemento da pena privativa de liberdade. (...) Ademais,...ao não se encontrar o bem objeto do contrato de alienação fiduciária, pode-se perfeitamente considerar o cometimento do crime de apropriação indébita, previsto no art. 168 do Código Penal. Nessa hipótese, poderá o réu nem sequer ser levado à prisão, podendo ser beneficiado com a suspensão condicional do processo. ${ }^{21}$

Em verdade, vive-se um momento de reflexão sobre a descriminalização de várias condutas eminentemente penais, o sistema carcerário encontra-se em crise mundial sem precedentes, as autoridades políticas e os estudiosos vêm empreendendo enorme esforço em encontrar soluções que quase sempre tem desaguado na adoção da pena alternativa em substituição a prisãa ${ }^{22}$.

\footnotetext{
2n Opinião esposada pela Professora Edna Luiza Nobre Galvão, no artigo publicado Depositáno infiel

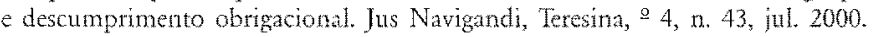

2 CARNEIRO, André. Breves comentários acerca da prisão civil decorrente da alienação fiduciária en garantia. Disponível en http:/www1.jus.com.br/doutriaa/textoasp?id=4107. Acesso em 20/10/03

32 COSTA, Cezar Augusto Rodrigues. Revista CIDADANIA E JUSTIÇA da Associaçào dos Magistrados Brasileiros, ano 2, $\mathrm{n}^{\mathrm{a}} 4,1^{\text {it }}$ semestre de 1998.
} 
Aliás, importante ressaltar que o referido Decreto-lei foi editado por uma Junta Militar, com base nos Atos Institucionais n. 5 e 12, de 1968 e 1969 , inserido num contexto ditatorial e sob a pressão de alguns economicamente interessados em resolver uma mera obrigação civil com o cerceamento da liberdade do comprador inadimplente.

Para trazer à eficácia a velada intenção, o Poder Executivo, não bastando as garantias próprias da alienação fiduciária, deu origem a um outro tipo de prisão civil, equiparando o devedor-fiduciante ao infiel depositário, com todas as responsabilidades que a este incumbem de acordo com a lei civil.

Esse assunto, entretanto, ê afeto à interpretação e aplicação de normas no tempo e no espaço, bem como da acepção que se tem acerca da hierarquia de normas e conforme o prisma que se adote, o posicionamento poderá ser totalmente diverso.

No campo da exegese, impende considerar que por ser a prisão do depositário infiel exceção no texto constitucional, tal norma deve ser interpretada restritivamente. A Carta Magna de 1988 firmou expressamente os casos em que seria cabível a prisão civil decorrente de dívidas, em preceito claro e exaustivo, e nesses casos, não consta a prisão do devedor inadimplente do contrato de alienação fiduciária, não se devendo assim, realizar interpretação extensiva em regra restritiva de liberdade.

Ademais, é inconcebível a equiparação de uma norma à outra, quando esta é restritiva de direitos. E é exatamente isto que ocorre com o artigo 66 da Lei. n. ${ }^{a} 4.728 / 65$, que equipara o devedor a um depositário, atribuindo-lhe inclusive, todas as obrigações que a este competem ${ }^{23}$.

Não se pode admitir, dessa forma, uma interpretação analógica extensiva em casos como este em que há notório prejuízo ao devedor, privando-o em sua liberdade em decorrência de uma dívida civil ${ }^{24}$.

De fato, os casos que a Constituição excepciona ao permitir a prisão civil, devem, como tais, ser interpretados restritivamente, como já foi dito.

A hermenêutica, como se vê, não permite esse tipo de equiparação (in pejus), de forma a ampliar-se um preceito restritivo da liberdade individual, violador do princípio da reserva constitucional ${ }^{25}$.

23 MAZZUOL, Valéro de Oliveira. Alienação frduciaria en garantia e a prisảo do devedor-fiduciante. p. 43 ess.

It Neste sentido opina Mário Gumarães de Souza: Nesta matéria, em que está em jogo a liberdade do cidadăo, a interpretaçâo ten que ser stricti juris, não sendo dado aplicar a pena de prisão por analogia, extensão ou paridade (in Da Prisão Civil, p. 116).

"MAZZUOLI, op. cit., p. 44. 
Por outro prisma que se analise, qual seja, o da natureza do contrato de depósito, a posição contrária à prisão civil não se altera.

Como bem observa o Ministro Luiz Vicente Cernicchiaro. A Constituição da República autoriza a prisão civil, por dívida, em dois casos: inadimplemento voluntário e inescusável de obrigação alimentícia e a do depositário infiel (art. 5a , LXVII). Cumpre, no entanto, distinguir duas situaçôes: a) o depósito é a obrigação principal; b) o depósito é a obrigação acessória. No primeiro caso, o depositário deve restituir a coisa, conforme o convencionado; segundo, o depósito reforça a obrigação de cumprimento de contrato. A prisão civil é restrita à primeira hipótese. Impossível estendê-la à segunda, sob pena de a restrição ao exercício do direito de liberdade ser utilizada para impor ao devedor honrar dívida civil. Interpretação coerente com a evolução histórico-política dos institutos jurídicos ${ }^{26}$.

Também considerando a natureza do contrato de depósito, pondera o professor João Luiz Alves, que ... o Código só considera depósito o que os autores denominam depósito regular, isto é, a entrega para guardar, de coisa natural ou convencionalmente não fungível, isto é, que não possa, na restituição, ser substituída por outra ${ }^{27}$.

Ora, tais afirmações encontram guarida no próprio conceito do contrato de depósito, uma vez que este tem como objeto "coisa móvel alheia".

De fato, a alienação guarda características próprias, tanto é que não se confunde com figuras que, à primeira vista, a ela poderiam se equiparar ${ }^{28}$.

Para os filiados a este argumento, existe uma equiparação legal do fiduciante ao depositário limitada ao aspecto formal, ou seja, para que haja a ameaça de prisão civil em caso de descumprimento da obrigação. O fiduciante, nesta linha, usa o bem fiduciado como se fosse dono, sem qualquer preocupação de custodiá-lo. Ex exatamente tal característica que desnatura o contrato de depósito no contexto da alienação fiduciária.

Corroborando tal afirmação, deve-se levar em conta que a depreciação do objeto em decorrência do uso não pode levar o fiduciário a indagar sobre o seu estado, na ação de depósito. ${ }^{29}$

André Luiz de Andrade Carneiro, filiado à tese da impossibilidade de se incluir o contrato de depósito nos ditames do Decreto 911, afirma:

\footnotetext{
${ }^{26}$ In Revista do STy n. 67, p. 146.

${ }^{27}$ ALVES Joăo Luiz. Codigo Civil, p. 362.

${ }^{23}$ Como suscintamente exposto no item 2.3 .

$2 \%$ neste sentido, RT $458 / 178$.
} 
Primeiramente, deve-se ter em vista que o contrato de depósito possui como principal característica, o fato de o depositante confiar a guarda e conservação de algum bem móvel, ou imóvel nos termos da lei 9514/97, à pessoa do depositário, que, nos termos da lei, se encontra expressamente proibido de utilizar a coisa, devendo restituí-la prontamente, quando solicitada pelo depositante.

Fácil concluir que o contrato de depósito em nada, absolutamente nada, relaciona-se com o contrato de alienação fiduciária em garantia, justamente pelo fato de que neste, o devedor obtém um financiamento para a aquisição de um bem, e automaticamente é instado na posse deste bem, para usá-lo da maneira que bem entender, fato que, consoante foi afirmado, não se faz possível no depósito.

Tomemos o exemplo do financiamento de um automóvel, que é o mais corriqueiro. $\mathrm{O}$ devedor faz o financiamento perante um Banco, por meio do contrato de alienação fiduciária, dando o próprio veículo como garantia de pagamento, porém, este devedor já passará à utilizar-se do bem, como melhor entender, pois, não seria razoável pensar que após a realização do contrato, devesse o automóvel permanecer parado, inerte, sem utilização alguma, aguardando o cumprimento total da avença com a quitação das parcelas.

Reforçando o exposto, em diversos países inexiste a possibilidade de segregação do depositário que não cumpriu seu mister. Neste sentido, Lucio Ricca ${ }^{30}$, expõe o direcionamento italiano:

...a abolição do instituto de que se trata não é tanto devida à soberana vontade quanto à sensibilidade do legislador, intérprete de uma exigência geral de ordem social, que se impõe como fundamental tendência de todo o sistema.

Seguindo a mesma orientação de se vedar, sem exceções, a possibilidade de prisão civil por dívidas, tem-se a Constituição do México, do Paraguai, bem como do Uruguai e da Suíça.

Para José Miguel Garcia Medina ${ }^{31}$, No direito brasileiro, é vedada a prisão do depositário infiel apenas no que toca ao inadimplemento do contrato de depósito. Quanto ao depositário judicial, permanecem em vigor as normas que regulam a possibilidade de sua prisão, que não foram atingidas pelo Pacto de São José da Costa Rica.

Já para José Geraldo de Jacobina Rabello ${ }^{32}$, a liberdade deveria manterse a salvo de procedimentos como o da equiparação em causa, que foi

apud MOREIRA ALVES, José Carlos. Op.cit, p.96.

31 MEDINA, José Miguel Garcia. Execução Givil. São Paulo, Revista dos Tribunais, 2002, p.371

${ }^{2}$ RABELLO, José Jacobina. Alienaçäo Fiduciária em Garantia e Prisăo Civil do Devedor. $2^{\circ}$ ed. $5 a ̈ o$ Paulo: Saraiva, 1987, p. 155. 
ditada para assegurar interesses voltados para o desenvolvimento econômico, ainda que ao preço daquela, não se podendo, nas circunstâncias, reconhecer a existência de depósito, verdadeiramente, na alienação fiduciária.

O contrato de alienação fiduciária não pode ser equiparado com o de depósito, visto que há disparidade de escopos no momento da formação dos mesmos. Neste sentido, o artigo 112 do Código Civil: Nas declarações de vontade se atenderá mais à intenção nelas consubstanciada do que ao sentido literal da linguagem.

No depósito, a finalidade é a guarda do bem pelo depositário até que o depositante o reclame, já na alienação fiduciária, o objetivo do devedor-fiduciante é a aquisição do bem e não sua guarda, porém para que o mesmo consiga efetuar esta aquisição é necessário que se realize uma garantia contra seu débito, então, o mesmo bem que é objeto da alienação é utilizado para servir de garantia da dívida.

Deve-se ter em mente, outrossim, que o objetivo do credor-fiduciário é efetuar o crédito que é sua maior fonte de rendas em razão do parcelamento (incluindo-se acréscimos, juros etc.)

E, em assim sendo, não caberia aceitar a inserção ou transformação do contrato de alienação fiduciária em depósito, sob pena de desfiguração do instituto.

Ao depositário não se atribui o dever de custódia de bem, muito menos o dever de restituí-lo quando exigido. $O$ que existe na alienação fiduciária é um desnaturamento da finalidade essencial desse tipo de contrato, que não é, deveras, o de depósito.

Não há como, portanto, efetuar-se uma verdadeira transmudação do contrato de depósito para encaixá-lo nos moldes e termos da legislação aplicável ao contrato de alienação fiduciária em garantia.

Eduardo Talamini explora essa idéia ao afirmar que se a constituição estipulou duas hipóteses taxativas e exaustivas em que cabe a prisão civil, não é possivel que a legislação infraconstitucional - manipulando os conceitos tradicionais para além daquele núcleo mínimo - altere o alcance dessas exceções, ampliando-o ${ }^{33}$.

Diante disto, por mais este particular não há como se admitir a possibilidade de aprisionar-se alguém por dívida contraída, em cuja posse direta esteja do bem garantidor da mesma e dele se desfaça por qualquer motivo. É que na alienação fiduciária, o depósito existe para a garantia do crédito, e não para a guarda do bem.

"TALAMINI, Eduardo. Prisăo civil e penal e "execuçäo indireta". In Teresa Arruda Alvim Wambier, Processo de execuçio e assuntos afins p. 144. 
Também considere-se que o depositário tem o dever de devolver a coisa (posto que de outrem) e o devedor-fiduciante, ao findar-se o seu contrato, não. Aliás, ocorre justamente o contrário: este paga, cumpre o contrato exatamente para adquirir a propriedade irrestrita do mesmo.

Ao contrário do contrato de depósito, onde o depositário é mero guardião do bem, o devedor-fiduciante exerce, também, a condição de proprietário do bem alienado, ainda que essa propriedade esteja pendente de cláusula resolutiva ${ }^{34}$

Há quem considere a possibilidade de se equiparar o devedor fiduciante ao depositário ${ }^{35}$ entretanto, tal entendimento não pode subsistir.

Sem embargo dos argumentos acima, ainda considere-se que entre instituição financeira e devedor-fiduciante estabelece-se uma relação de consumo, o que torna imprescindível a aplicação do $\mathrm{CDC}$, que prevê em seu artigo 42 , que $\mathrm{Na}$ cobrança de débitos, o consumidor inadimplemento não será exposto a ridículo, nem será submetido a qualquer tipo de constrangimento ou ameaça.

E não há que se negar que poucas situações demonstrar-se-iam tão vexatórias quanto a prisão de um ser humano; o seu encarceramento junto com criminosos de toda natureza em estabelecimento público destinado ao recolhimento de pessoas das mais variadas índoles.

Ao par da doutrina, a jurisprudência também tem se mostrado titubeante quanto ao assunto.

Em nosso País, o Superior Tribunal de Justiça decide contrariamente à prisão por dívida contraída por contrato de alienação fiduciária - negando, portanto, a existência de contrato de depósito naquele instrumento agindo em divergência com as decisões proferidas pela Corte Suprema ${ }^{36}$.

\footnotetext{
it Distinção efetuada nos autos de Al n. 96.0010700, de 13.05.1997, do TJRO.

3. Césat Fúza é partidário da prisăo, entendendo que näo sendo efetuado o pagamento, deve o devedor, que normalmente fica na posse direta do bem, entregaj-lo ao adquirente, sob pena de prisăo. Neste sentido, a própria Lei $4728 / 65$ diz equiparar a depositário infiel o devedor alienante, que, sem motivo justo, se nega a restituir a coisa : nada bá de ilegal na prisão do depositário infẹl. Luiz Rodrigues Wambier, por seu turno, afirma:O que se te sustentado em abono dessa tese, que ao que nos parece é mais correta, é o que o conceito de depósito expresso no texto constitucional (art. 5ä, LXVII) contém más do que a figura contratual do deposito previsto no Código Civil, pois se trata de expressão de caráter genéricos, absolutamente apto a albergar tanto o deposito tradicional do Código Civil, quanto as novas modalidades de deposito.

3. Alienação fiduciária. (Lei 4728/65 e Decreto 911/69). Prisäo civil (faita de cabimento). Segurdo decisão da corte especial do ST], é ilegítima, ou é ilegal a prisão civil do alienante ou devedor como depositário infiel (eresp 149.518). Da terceira turma, MC 1709 e HC 8324. Recurso especial conhecido e provido. (Participaram da votaço os Ministros Eduardo Ribeiro, Waldemar Zveiter, Ari Pargendler e Menezes Direto) Superior Tribunal de Justiç. Recurso especial $222242 / \mathrm{mg} 04.10 .19993$ turma. Relator Ministro Eduardo Ribero, e anda Alienaça fiduciania. Prisáo civil. A incorporaça a nosso ordenamento jurídico das disposiçóes constantes do Pacto de São José de Costa Rica elimina a possibilidade de ptisão civil, tratando-se de alienaçăo fiduciatia. (Participaram da votaçăo os Ministros Waldemar Zverter, Ari Pargendler, Menezes Direito E Nilson Naves). Superior Tribunal De Justiça Medida cautelar $189 \% / \mathrm{sp} 11.10 .19994$ turma. Relator Ministro Salvio De Figueiredo Teineira.
} 
Os argumentos dos ministros do STJ, na maioria das vezes, fundam-se na extensão do artigo $5^{a}$, LXVII aos contratos de alienação fiduciária, vedando-se-a.

Por fim, no que pertine ao Direito Internacional, embora a prisão civil esteja prevista no texto constitucional, a partir do Decreto Presidencial 592/ 92, de 6.7.1992, passou a integrar em nosso sistema juridico o Pacto Internacional de Direitos Civis e Políticos que, em seu art. 11, dispõe que Ninguém poderá ser preso apenas por não poder cumprir uma obrigação contratual.

Além deste Diploma, o Pacto de São José da Costa Rica, em seu artigo $7^{a}$, dispõe que Ninguém deve ser detido por dívidas. Este princípio não limita os mandatos de autoridade judiciária competente expedidos em virtude de inadimplemento de obrigação alimentar.

Tal dispositivo quer significar que alguém somente poderá ser preso por dívida caso descumpra obrigação alimentícia, e em nenhuma outra hipótese mais, mesmo no de depositário infiel.

Em 09.11.92, através do Decreto 678/92, este Pacto passou a integrar o ordenamento juridico brasileiro, sendo que esse princípio limita os mandados de autoridade judiciária competentes expedidos para fins de prisão somente para aqueles processos em que se discute inadimplemento de obrigação alimentar.

No que pertine à convivência do Pacto de São José da Costa Rica com a Constituição Federal, é importante dizer que os que defendem a impossibilidade de prisão por dívida contraida em contrato de alienação fiduciária, fazem uma interpretação sistemática da Carta Magna, que proclama em seu art. 4.., II, que o Brasil se rege em suas relações internacionais pelo princípio da prevalência dos direitos humanos.

Valério Mazzuoli é um dos defensores deste argumento: A prisão civil do devedorfiduciante é terminantemente proibida no atual contexto da legislação brasileira..."

De fato, a regra constitucional deve estar sempre apta a inspirar o surgimento de novas normas, capazes de responder eficazmente às novas exigências da sociedade.

Reforçando a presente tese, veja-se o teor do parágrafo $2^{-a}$ do artigo $5^{\text {a }}$ da Lei Maior, que dispõe acerca dos direitos e garantias fundamentais: Os direitos e garantias expressos nesta Constituição não excluem outros decorrentes do regime e dos princípios por ela adotados, ou dos tratados internacionais em que a República Federativa do Brasil seja parte. Isso afasta o argumento contrário, no sentido de não ter havido a recepção do referido Pacto em nosso ordenamento. 
Além disto, a mesma Carta, em seu art. 1.․․, III, prevê que o Brasil constitui-se em Estado Democrático de Direito, tendo como fundamento a dignidade da pessoa humana.

No que tange a este princípio, a proteção aos direitos da personalidade, tão importantes em nosso cotidiano, deve, nos dizeres de Gustavo Haddad $J^{\prime}$ abur ${ }^{38}$, renovar a preocupação sociojurídica em conter os abusos espraiados contra os bens personalíssimos, dos quais dependem, sem rebuço de dúvida, antes da satisfação, a própria razão de viver.De fato, a dignidade da pessoa humana é fundamento da República e sua importância é inegável: "A pessoa humana não é, como dito antes, apenas um dado ontológico, mas traz encerrada em si uma série de valores que the são imanentes. A dignidade da pessoa humana é o centro de sua personalidade, e portanto merece a maior proteção possível. Aliás, a conjugação personalidade-dignidade é tão forte que boa parte dos autores que tratam do tema referem-se diretamente à proteção da dignidade do homem. Essa ligação é, assim, indissolúvel."39

Assim pode-se dizer que dignidade da pessoa humana é o valor básico fundamentador dos direitos fundamentais, edificados, assim, em alicerces da ordem pública, pois possibilitam o desenvolvimento integral do ser humano, exigido por sua dignidade, conforme Pietro Perlingieri ${ }^{40}$ : "A tutela da dignidade deve realizar-se em relação a todos os aspectos, sem, porém, que se deva traduzir na mesma situação de vantagem e na noção de direito subjetivo. A diversidade dos interesses fundamentais do homem não se traduz em uma pluralidade de direitos fundamentais diversificados por conteúdo e por disciplina (...) O que releva é o valor da pessoa unitariamente entendida."

Daí concluir-se que a vontade do legislador foi a de autorizar a incorporação do produto normativo convencional mais benéfico, pela porta de entrada do seu art. 5.,$\S 2$. , que tem o caráter de cláusula aberta à inclusão de novos direitos e garantias individuais provenientes de tratados.

A prevalência dos direitos humanos, enquanto princípio norteador das relaçôes exteriores do brasil e fundamento colimado pelo país para a regência da ordem internacional não implica tão-somente o engajamento no processo de edificação de sistemas de normas vinculados ao direito internacional público. impõe-se buscar a plena integração das regras de tais

\footnotetext{
12 JABUR, Gustavo Haddad. Liberdade de Pensamento e Direito à Vtda Privada. Conflitos entre Direitos da Personalidade. São Paulo: Editora Revista dos Tribunais, 2000, p.21

34 CORTIANO JR, Eroulths. Alguns apontamentos sobre os chamados direitos da personalidade. Repensando os fundamentos do Direito Civil Brasileiro Contemporâneo.

4PERLINGIERI, Pietro. Perfis do Direito Civi, p.159
} 
sistemas à ordem jurídica interna de cada estado, o que ressalta a importância do já mencionado $\$ 2^{a}$ do artigo $5^{\mathrm{a}}$ da constituição brasileira de 1988, que dá plena vigência aos direitos e garantias decorrentes 'dos tratados internacionais em que a república federativa do brasil seja parte ${ }^{41}$.

Não se tem dúvida de que o direito à não prisão do infiel depositário, é um direito decorrente de um dos princípios pela República Federativa do Brasil acima mencionados.

Assim, com base na própria Carta Constitucional, deve-se entender que, em se tratando de direitos humanos provenientes de tratados internacionais em que a República Federativa do Brasil seja parte, há de ser sempre aplicado, no caso de conflito entre o produto normativo convencional e a Lei Magna Fundamental, o princípio da primazia da norma mais favorável às vítimas ${ }^{42}$. Por fim, mister comentar o teor do artigo 652 do Código Civil vigente ${ }^{43}$. Há quem entenda que a possibilidade da prisão foi restabelecida com o advento do Código Civil de 2002, como Inácio de Carvalho Neto:

(...) ) embora sempre houvesse permissão constitucional, não era possivel no Brasil a prisão civil do depositário infiel, em face da inexistência de lei em vigor que a determinasse, sendo que a lei que a determinava foi revogada pela Convenção Americana sobre Direitos Humanos (Pacto de São José da Costa Rica), tendo agora sido restabelecida pelo novo Código Civil. ${ }^{44}$

Todavia, o dispositivo inserido na nova legislação civilista é claramente inconstitucional, em vista dos argumentos já expostos. O Código $\mathrm{Ci}$ vil, infelizmente, incide no equívoco de se determinar a prisão do devedor, em total contrariedade às normas que the sobrepõem.

Deste modo, observa-se que caem por terra todos os argumentos favoráveis à restrição da liberdade pessoal do cidadão na hipótese da infidelidade depositária.

\section{Conclusão}

Diante do argumentado, plausível e possível o entendimento esposado pelo Supremo Tribunal de Justiça, no sentido de não aceitar a pena de prisão para o devedor-fiduciante.

" DALLAR, Pedro. Constituiç̃o e relaçôes exteriores, p. 162.

${ }^{42}$ Nomenclatura utilizada pelo professor Antonio Augusto Cançado Trindade, na obra A proteção internacional dos direitos humanos: fundamentos jurídicos e instrumentos básicos, p. $630-5$.

${ }^{43}$ Art. 652 . Seja o depósito voluntário ou necessáto, o depositário que năo o restituir quando exigido será compelido a fazêto mediante prisão não excedente a um ano, e ressarcir os prejuízos.

4 CARVALHO NETO, Inácio de. A prisia do depositário infiel, o Pacto de Säo José da Costa Rica e o Novo Código Civil. Disponivel em hitp:/www.juspodivm.combr/novodireitocivil/artigos/convidados/a_priso do_deposito_infiel.pdt. Acesso em $\% / 10$ 
E, em assim se falando, pondera-se que também cabível e pertinente o pensamento que se dirige à não inserção do contrato de depósito no contexto do contrato de alienação fiduciária para fins de decretação da mencionada pena.

Por óbvio, este entendimento pode ser rebatido e contra-argumentado de diversas maneiras, mas há que se argüir: qual o bem mais valioso a ser protegido pelo Estado? O patrimônio ou a incolumidade fisica e psíquica dos cidadãos?

É certo que a prisão é um meio coercitivo bastante eficaz para atingirse o desiderato de ver-se dívidas adimplidas - desejo maior do credor mas, se fosse o único meio, como sobreviveriam no mundo jurídico os demais meios de cobrança/execução de dívidas?

Assim, facilitar o recebimento às instituiçôes financeiras não é forma de fazer-se justiça, mas sim de se instaurar a desigualdade entre os componentes da sociedade, uma vez que o homem comum não dispõe de um veículo tão potente de indução ao pagamento como a prisão.

E em não o conhecendo o cidadão comum - por indisponível - não é certo dizer-se que se está aplicando rigorismo às relações negociais atuais.

A título de ilustração, cite-se as considerações de Filangiere, que tão bem retratam a condição do devedor no contrato em comento:

Punir constantemente a insolvabilidade pela prisão; confundir a miséria com o crime; cobrir o inocente de toda a infâmia da perversidade, em lhe arrancando a honra; forçá-lo a renunciar a virtude; tirar de um homem de bem infeliz até a propriedade do seu corpo, que o destino inexorável the há deixado; fazê-lo comprar por um suplício, muitas vezes eterno, o ligeiro alívio, que ele tinha obtido em seu infortúnio; condenar à inação, aos tormentos e aos vícios, que a acompanham, aquele que não tem mais que os seus braços, ou os esforços do seu espírito, para fazer subsistir sua família e pagar seu credor; privar a sociedade de um homem que não a tem ofendido, e que the poderia ser útil; dar a um credor implacável o poder de conservar o seu devedor neste estado de opróbio e de desolação tanto tempo quanto ele quiser, e de satisfazer sua vingança com as armas da lei; em uma palavra, ofender a justiça, ultrajar os direitos mais preciosos do homem e do cidadão, e multiplicar as infelicidades da indigência sem favorecer as propriedades - tais são os abusos da prisão por dívidas, estabelecida em todos os países da Europa mesmo entre aqueles que mais se gloriam da sua humanidade e de sua liberdade ${ }^{45}$.

45. Fingiere, *apud» Lobăo, Execuçôes, pag $145, \$ 181$, citado em RODRIGUES FILHO, Eulampio. Prisăo civil sem lei. Un equivoco. Jus Navigandi, Teresina, a. 6, n. 52, nov. 2001. 
Ainda, com supedâneo nas lições de Paulo Restiffe Neto e Paulo Restiffe ${ }^{46}$ :

O que não tem faltado na alienação fiduciária é reflexão, até pela característica própria de todo instituto jurídico novo ou em evolução, pelas alterações que produz nos padrões sedimentados, na ordem jurídico-econômico-social.

Em que pese a "maioridade biológica" da alienação fiduciária em garantia, a sua estrutura não está "madura".

Como já mencionado, o Pacto de São José da Costa Rica aboliu expressamente qualquer forma de prisão civil por dívida, ressalvando-se a hipótese de inadimplemento de obrigação alimentícia (e tão somente esta exceção se verifica).

Tal tratado, inegavelmente inserido em nosso ordenamento com status de norma constitucional, vez que trata de direitos humanos, sobrepõe-se à normatização diversa no que pertine à possibilidade de se segregar o infiel depositário.

O Pacto supra-referido está em plena vigência, derrogando todas as previsóes legislativas de caráter de lei geral sobre prisão civil e os procedj. mentos para sua aplicação, por infidelidade depositária. Por outro lado, O Decreto 911 foi esvaziado por não cominar prisão, mas tão somente fazer remissão à fonte cominatória derrogada.

O dispositivo que equipara a alienação a contrato de depósito e, por via obliqua, admite a prisão civil, foi criado em atendimento aos interesses das grandes corporações financeiras da época em que foi editada a norma. A interpretação, nesse caso, deve ser restritiva, sendo inconcebível a equiparação.

O artigo 652 do Código Civil Brasileiro, por sua vez, é inconstitucional, à medida em que contraria as normas que lhe sobrepõem acerca da impossibilidade da segregação do depositário infiel.

Outrossim, a opção pela alienação fiduciária muitas vezes se dá pela impossibilidade de prestação de outras espécies de garantia pela maioria dos cidadãos, tendo em conta a dificil situação econômica vivenciada no país.

Destituindo-se a intenção de se esgotar o assunto, deve-se refletir acerca do instituto, mormente em se considerado a situação em que o depositário não cumpre com sua obrigação, sempre visando os resultados práticos.

De fato, o instituto da prisão civil por dívida foi perdendo a crueldade de se constranger o indivíduo, em nome do cumprimento de uma obrigação de caráter civil. Com o princípio da execução patrimonial, não mais se justifica o atingimento à liberdade dos cidadãos sob esta justificativa.

\footnotetext{
* RESTTFEE NETO, Paulo; RESTIFFE, Paulo. Prisão civil do depositário infele em face da derrogação do artigo 1284 do Codigo Crvil pelo Pacto de São José da Costa Ríca. RT 756/37, outubro de 1998. 
O devedor civil deve resolver a sua pendência segundo as regras do Direito Civil e do Direito Processual Civil, não podendo jamais se submeter, por qualquer motivo, à prisão, sob pena de se retornar ao estado medieval.

Utilizando-se da veeemente defesa da liberdade apresentada por Álvaro Villaça Azevedo ${ }^{47}$, reforça-se tal tese:

Não é de crer-se correto, no mundo jurídico atual, que, após as negativas lições do passado, quanto à admissão desse instituto do aprisionamento por dívida, que ainda existam resquícios dessa inadmissível coerção.

Deve-se também mencionar, por oportuno, que a imposição de coerção nesse nível de gravidade ocorre em razão exclusivamente econômica, ou seja, para atender a interesses maiores. Entretanto, verificando-se a existência de mecanismos processuais hábeis a se atingir o descumprimento do mister do depositário, não há que se falar em interferência em sua liberdade pessoal. Não se ignora o fato de que os instrumentos processualmente previstos não são irretocáveis. Deveriam, indubitavelmente, ser mais eficazes. Mas tais falhas não justificam a coerção pessoal.

Considerando o papel do julgador, deve-se acatar a tendência de se abolir a execução pessoal com vistas à realização de uma efetiva justiça:

A atividade do legislador é apenas o início do ciclo de atuação normativa, que somente se encerrará com a participação do magistrado, a quem caberá aplicar a regra ao caso concreto, dirimindo a lide e realizando a tão almejada paz social. ${ }^{48}$

Deve haver, sim, uma preponderância dos direitos de personalidade, inclusive em atendimento ao princípio da dignidade da pessoa humana, sob pena de se estar retrocedendo e se utilizando de mecanismos já ultrapassados de punição.

Como afirma Valério Mazzuoli49 ${ }^{49}$, pode-se ter a impressão de impunidade do devedor, quando se afasta a possibilidade da prisão, vez que não ficaria ao alcance da letra da lei. Porém, não se pode conceber que seja conferido a uma lei ordinária um alcance que não the dá a Lei Maior.

Mais uma vez com esteio nas pertinentes observações do Professor Álvaro Villaça Azevedo ${ }^{50}$, há que se considerar que no Direito Privado, o Estado deve intervir, para reequilibrar as relações privadas, descumpridas sem agredir direitos da personalidade. O Direito, cientificamente criado, ao sabor dos tempos, não pode sofrer penadas de conveniências passageiras, para atendimento de preferências, em detrimento da própria sociedade.

\footnotetext{
47 AZEVEDO, Alvaro Villaça. Prisăo Civil por Dívida. São Paulo: Revista dos Tribunais, 1993, p.11

4 GAGLIANO Pablo Stolze. O Juiz co Novo Código Civil Brasileiro. Disponivel em hetp:// www.juspodivm.com.br/novodireitocivil/artigos/pablo/juiz_codcivil.pdf, capturado em 20/10/03.

4: MAZZUOL, Valério de Oliveira. Prisão Civil por divida e o pacto de \$ão josé da Costa Rica: enfoque para os contratos de alienação fiduciária em garantia. Texto extraido do Jus Navigandi, http: // www1,jus.com.br/doutrina/texto asp?id=624, capturado en 21/10/03.

: AZEVEDO, Alvaro Villaça. Op.cit, p.155
} 


\section{BIBLIOGRAFIA}

ACQUAVIVA, Marcus Cláudio. Dicionário Jurídico Brasileiro. São Paulo: Jurídica Brasileira, 1994.

ALVES, João Luiz. Código Civil. $3^{\circ}$ ed., $4^{a}$ vol., Rio: Borsoi, 1958.

ANDRADE, José A. F. de. Da Alienação Fiduciária em Garantia. São Paulo: Edição Universitária de Direito, 1970.

AZEVEDO, Álvaro Villaça. Prisão Civil por Dívida. São Paulo: Revista dos Tribunais, 1993.

BADARO, Ramagem. Fisionomias civil, processual e penal da alienação fiduciária em garantia. São Paulo: Juriscrédi, 1972.

BEVILAQUA, Clóvis. Código Civil dos Estados Unidos do Brasil - comentado. Edição histórica, Rio de Janeiro: Editora Rio, 1977.

CANÇADO TRINDADE, Antonio Augusto. A proteção internacional dos direitos humanos: fundamentos jurídicos e instrumentos básicos. São Paulo: Saraiva, 1991.

CARNEIRO, André Luiz de Andrade. Breves comentários acerca da prisão civil decorrente da alienação fiduciária em garantia . Jus Navigandi, Teresina, a. 7 , n. 66, jun. 2003. Disponivel em: <http://www 1.jus.com.br/doutrina/ texto.asp?id=4107>. Acesso em: 13 out. 2003.

COSTA, César Augusto. Da prisão civil por dívida. Revista CIDADANIA E JUSTIÇA da Associação dos Magistrados Brasileiros, ano 2, $\mathrm{n}^{\mathrm{a}}$ 4, $1^{\text {a }}$ semestre de 1998.

DALLARI, Pedro. Constituição e relações exteriores. São Paulo: Saraiva, 1994. DIEDRICH, Luiz. Da inconstitucionalidade da prisão do depositário infiel. Disponivel em http $/ / \mathrm{www}$.direito.com.br/Doutrina.asp? $\mathrm{O}=1 \& \mathrm{~T}=421$. Acesso em 19/10/2003.

DIEZ-PICAZO, Luiz. Fundamentos del Derecho Civil Patrimonial. Madrid: Civitas, 1996, p.123

FACHIN, Luiz Edson (coordenador). Repensando os fundamentos do direito civil contemporâneo. Rio de Janeiro: Renovar, 1998.

FIUZA, César. Alienação Fiduciária em Garantia. Rio de Janeiro: AIDE, 2000. GAGLIANO, Pablo Stolze. A Prisão Civil do Devedor de Alimentos. Disponivel em http:/www.juspodivm.com.br/novodireitocivil/artigos/pablo/ prisao_civil_do_devedor_de_alimentos.pdf. Acesso em 18/10/2003. 
GALVÃO, Edna Luiza Nobre. Depositário infiel e descumprimento obrigacional. Jus Navigandi, Teresina, a. 4, n. 43, jul. 2000. Disponivel em: http:/www1.jus.com.br/doutrina/texto.asp?id=601. Acesso em 13 out. 2003. GOMES, Orlando. Alienação Fiduciária em Garantia. São Paulo: Revista dos Tribunais, 1970.

GOMES, Orlando. Contratos. $12^{\circ}$ ed., Rio de Janeiro: Forense, 1993. JABUR, Gustavo Haddad. Liberdade de Pensamento e Direito à Vida Privada. Conflitos entre Direitos da Personalidade. São Paulo: Editora Revista dos Tribunais, 2000, p.21

MATTIROLO. Comentários ao CPC. $2^{\circ}$ ed., São Paulo: Revista dos Tribunais, 1976.

MAZZUOLI, Valério de Oliveira. Alienação Fiduciária em Garantia e a Prisão do Devedor-Fiduciante. Campinas: Agá Juris, 1999.

MAZZUOLI, Valerio de Oliveira. Prisão civil por dívida e o pacto de São José da Costa Rica: enfoque para os contratos de alienação fiduciária em garantia. Jus Navigandi, Teresina, a. 4, n. 46, out. 2000. Disponivel em: <http:/ /www1.jus.com.br/doutrina/texto.asp?id=624>. Acesso em: 13 out. 2003. MEDINA, José Miguel Garcia. Execução Civil. Princípios fundamentais. Coleção Estudos de Direito de Processo ENRICO TULIO LIEBMAN. V.48. São Paulo: Editora Revista dos Tribunais, 2002.

MOREIRA ALVES, José Carlos. Da Alienação Fiduciária em Garantia. Rio de Janeiro: Forense, 1979.

OLIVEIRA, Valdeci Mendes de. Direito das Obrigações Aplicado. São Paulo: Edipro, 1996.

PERLINGIERI, Pietro. Perfis do Direito Civil: Introdução ao Direito Civil Constitucional. 2a. ed. Rio de Janeiro: Renovar, 2002.

RABELLO, José Geraldo de Jacobina. Alienação Fiduciária em Garantia e Prisão Civil do Devedor. $2^{\circ}$ ed. São Paulo: Saraiva, 1987.

RESTIFFE NETO, Paulo; RESTIFFE, Paulo. Prisão civil do depositário infiel em face da derrogação do artigo 1284 do Código Civil pelo Pacto de São José da Costa Rica in Revista dos Tribunais 756/37, outubro de 1998. RODRIGUES FILHO, Eulâmpio. Prisão civil sem lei. Um equívoco. Jus Navigandi, Teresina, a. 6, n. 52, nov. 2001. Disponível em: <http:// www1.jus.com.br/doutrina/texto.asp?id=2472>. Acesso em: 13 out. 2003. 
RODRIGUES, Sílvio. Direito Civil - Dos contratos e das declarações unilaterais de vontade. $3^{\mathrm{a}}$ vol., $7^{\circ}$ ed., São Paulo: Saraiva, 1977.

SOUZA, Mário Guimarães de. Da Prisão Civil. Recife: Jornal do Commércio S. A., 1938.

TALAMINI, Eduardo. Prisão civil e penal e "execução indireta", in. ALVIN WAMBIER, Teresa Arruda, coord., Processo de execução e assuntos afins. São Paulo: Revista dos Tribunais, 1998.

THEODORO JUNIOR, Humberto. Processo de Execução. $10^{\circ}$ ed. São Paulo: LEUD, 1999.

WALD, Arnoldo. Curso de Direito Civil Brasileiro - Obrigações e Contratos. $10^{\circ}$ ed., São Paulo: RT, 1992.

WAMBIER, Luiz Rodrigues. Busca e Apreensão na Alienação Fiduciária. Revista de Processo n⿳⺈ 93, p.66. 